Ethos (Jurnal Penelitian dan Pengabdian Masyarakat): 161-170

\title{
Peningkatan Peran Serta Masyarakat dalam Pengurangan Timbulan SAMPAH
}

\author{
${ }^{1}$ Yanti Sri Rejeki, ${ }^{2}$ M. Dzikron, ${ }^{3}$ Nugraha, ${ }^{4}$ Dewi Shofi M., ${ }^{5}$ Chaznin R.M, ${ }^{6}$ Jefri \\ Khairunnas, ${ }^{7}$ Hilda Syaidatul Ulfah, ${ }^{8}$ Aef Saefurrohman \\ 1,2,3,4,5,6,7,8 Fakultas Teknik, Program Studi Teknik Industri, Unisba \\ Email:'1ysrejeki@yahoo.com
}

\begin{abstract}
Abstrak. Bank sampah adalah salah satu strategi penerapan $3 R$ (Reuse,Reduce,Recycle) dalam pengelolaan sampah pada sumbernya di tingkat masyarakat. Pelaksanaan bank sampah pada prinsipnya adalah satu rekayasa sosial (social engineering) untuk mengajak masyarakat memilah sampah. Pelaksanaan bank sampah dapat memberikan output nyata bagi masyarakat berupa kesempatan kerja dalam melaksanakan manajemen operasi bank sampah dan investasi dalam bentuk tabungan (Kementrian Lingkungan Hidup, 2011). Ma salah utama yang dihadapi mitra saat ini adalah bank sampah yang telah terbentuk sejak tahun 2012 belum berkembang sesuai harapan dan dinilai belum optimal. Hal ini dapat dilihat dari penurunan jumlah nasabah. Analisis awal penyebab perkembangan Bank Sampah yang kurang optimal karena manajemen Bank Sampah belum dilakukan dengan baik dikarenakan keterbatasan sumberdaya. Oleh karena itu diperlukan kegiatan untuk meningkatkan peran serta masyarakat dalam mengurangi sampah. Kegiatan yang dilakukan adalah pelatihan, pendampingan, monitoring dan evaluasi. Pelatihan yang diberikan mengenai pemilahan sampah dan pembuatan kompos skala rumah tangga. Hasil dari kegiatan tersebut menunjukkan adanya peningkatan jumlah nasabah.
\end{abstract}

Kata Kunci : Penerapan 3R (Reduce, Reuse, Recycle), Bank Sampah, Pelatihan

\section{Pendahuluan}

Sampah menjadi masalah sehari-hari, jika mendengar istilah sampah yang terlintas dalam benak adalah setumpuk limbah yang menimbulkan aroma busuk yang menyengat. Sampah diartikan sebagai material sisa yang tidak diinginkan setelah berakhirnya suatu proses penggunaan. Sampah terdiri atas zat kimia, sisa energi atau makhluk hidup yang tidak mempunyai nilai guna dan cenderung merusak. Sampah dapat berupa materi padat, cair, atau gas.Untuk jenis materi cair dan gas terjadi emisi, terutama bila dikaitkan dengan polusi. Bila sampah masuk ke dalam lingkungan (ke air, ke udara dan ke tanah) maka kualitas lingkungan akan menurun. Peristiwa munculnya sampah ke lingkungan inilah yang dikenal sebagai pencemaran lingkungan.

Berdasarkan sumbernya sampah terbagi menjadi sampah alam, sampah manusia, sampah konsumsi, dan sampah produk industri. Sedangkan berdasarkan sifatnya sampah dibagi menjadi dua yaitu 1) sampah organik atau sampah yang dapat diurai contohnya daun-daunan, sayuran, sampah dapur dan lain-lain, 2) sampah an-organik atau sampah yang tidak terurai contohnya plastik, botol, kaleng dan lain-lain. Di lokasi 
tempat pembuangan sementara (TPS), sampah terus meningkat jumlahnya menuju ke tempat pembuangan akhir (TPA). Dengan semakin bertumpuknya sampah di TPS-TPA, akan menimbulkan bencana seperti pencemaran air dan pencemaran udara yang merugikan kesehatan secara umum. Selain dampak yang telah disebutkan, sampah yang menumpuk akan berpengaruh pada perubahan iklim akibat adanya kenaikan temperatur bumi atau yang lebih dikenal dengan istilah pemanasan global. Seperti yang kita ketahui adanya fenomena pemanasan global akibat peningkatan gas-gas rumah kaca seperti emisi gas karbondioksida (CO2), metana ( $\mathrm{CH} 4)$, dan dinitrooksida (N2O).Oleh karena itu, kita harus berusaha agar bencana tidak terjadi di lingkungan sekitar kita.Sudah saatnya sampah harus dikelola dengan prinsip dasar pengelolaan sampah yang ramah lingkungan yaitu diawali oleh perubahan cara pandang dan cara memperlakukan sampah. Pola Pembuangan sampah yang lama seperti kumpul, angkat baru buang tidaklah efisien karena dapat menimbulkan lingkungan menjadi tidak ramah dan menjadi sumber penyakit seperti malaria dan diare.Paradigma lama yang bertumpu pada tumpukan akhir sudah saatnya ditinggalkan dan diganti dengan paradigma baru.Paradigma baru yaitu memandang sampah sebagai sumber daya bernilai ekonomis untuk dimanfaatkan, misalnya untuk bahan an-organik di daur ulang atau dijadikan produk kerajinan, sedang bahan organik dijadikan kompos.

Prinsipnya adalah meminimasi timbulnya sampah, memanfaatkan-ulang, dan mendaur-ulang sampah (prinsip 3R, reduce, reuse, recycle) merujuk Peraturan Pemerintah Nomor 81 tahun 2012 tentang Pengelolaan Sampah Rumah Tangga dan Sejenis Sampah Rumah Tangga, pasal 1 ayat 7. Terdapat pula Undang-Undang RI No. 18 tahun 2008 tentang Pengelolaan Sampah, jika prinsip tersebut dijalankan akan mendatangkan output nyata, yaitu mengurangi beban polutan, mendatangkan manfaat ekonomi dan menjadikan lingkungan bersih, yang pada akhirnya menghasilkan outcome yang dapat langsung dirasakan, yaitu kesehatan dan penghasilan.

Bank sampah adalah salah satu strategi penerapan 3R (Reuse,Reduce,Recycle) dalam pengelolaan sampah pada sumbernya di tingkat masyarakat. Pelaksanaan bank sampah pada prinsipnya adalah satu rekayasa sosial (social engineering) untuk mengajak masyarakat memilah sampah. Pelaksanaan bank sampah dapat memberikan output nyata bagi masyarakat berupa kesempatan kerja dalam melaksanakan manajemen operasi bank sampah dan investasi dalam bentuk tabungan (Kementrian Lingkungan Hidup, 2011). Pembangunan bank sampah sebenarnya tidak dapat berdiri sendiri tetapi harus disertai integrasi dengan gerakan 3R secara menyeluruh di kalangan masyarakat.

\subsection{Analisis Situasi Bank Sampah Mekar Sakinah}

Sampah di perumahan Unisba Mandala Mekar Sakinah selama ini belum dikelola dengan baik, dimana sampah hanya menumpuk di Tempat Pembuangan Akhir (TPA) sampah di dalam komplek dan menimbulkan kekhawatiran akan menjadi masalah dikemudian hari. Berkaitan dengan hal tersebut, beberapa warga berinisiatif 
untuk mendirikan Bank Sampah di lingkungan komplek Perumahan Unisba. Bank sampah Mekar Sakinah diresmikan pada tanggal 4 Maret 2012 oleh Bapak Lurah Desa Mandala Mekar Kecamatan Cimenyan yaitu Bapak Ijang Suryana dan dihadiri oleh ketua RW 12 Bapak Asep Sugriatna dan ketua RT di lingkungan komplek Perumahan Unisba. Kegiatan pengumpulan sampah dilakukan setiap minggu ke-2 dan ke-4 setiap bulannya. Saat ini nasabah Bank Sampah Mekar Sakinah tercatat berjumlah 65 orang.Sedangkan untuk sampah organik/basah dibuat percontohan pembuatan pupuk kompos di dekat areal tempat pembuangan sampah. Berkaitan dengan peran serta masyarakat dalam pengelolaan sampah melalui pembentukan Bank Sampah, berikut beberapa potensi serta kendala yang dihadapi mitra (Tabel 1).

\subsection{Permasalahan Mitra}

Dari latar belakang yang telah diuraikan sebelumnya dapat diketahui bahwa masalah utama yang dihadapi mitra saat ini adalah bank sampah yang telah terbentuk sejak tahun 2012 belum berkembang sesuai harapan dan dinilai belum optimal. Analisis awal penyebab perkembangan Bank Sampah yang kurang optimal karena manajemen Bank Sampah belum dilakukan dengan baik. Ide dan inisiatif pendiri Bank Sampah yang sangat baik mengenai peran serta masyarakat dalam pengelolaan sampah melalui pembentukan Bank Sampah belum diiringi dengan manajemen Bank Sampah yang ada dengan baik pula.Selain itu juga kurangnya sosialisasi dan arahan kepada masyarakat menyebabkan rendahnya tingkat partisipasi masyarakat terhadap program Bank Sampah ini. Berikut beberapa perumusan mengenai permasalahan yang ada berkaitan dengan manajemen Bank Sampah :

1) Bagaimana proses bisnis yang diterapkan pada Bank Sampah Mekar Sakinah saat ini dan bagaimana proses bisnis yang tepat untuk Bank Sampah Mekar Sakinah?

2) Pelatihan apa yang diperlukan untuk meningkatkan kemampuan manajemen para pengurus Bank Sampah?

3) Upaya apa yang harus dilakukan untuk mengembangkan Bank Sampah dan meningkatkan partisipasi masyarakat terhadap keberadaan Bank Sampah?

\section{Tabel 1: Potensi dan Kendala yang Dihadapi}

\begin{tabular}{|c|c|}
\hline $\begin{array}{c}\text { Potensi dan sumber daya yang } \\
\text { dimiliki }\end{array}$ & Kendala / masalah yang dihadapi \\
\hline $\begin{array}{l}\text { Inisiatif masyarakat untuk } \\
\text { berperan aktif dalam pengelolaan } \\
\text { sampah dengan membentuk } \\
\text { BankSampah }\end{array}$ & 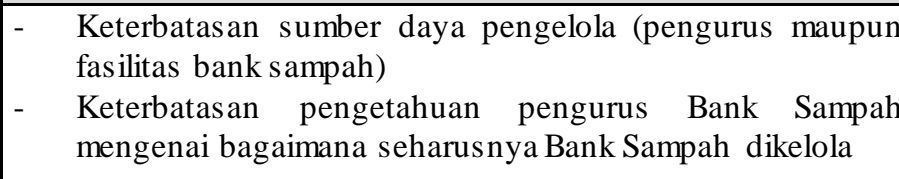 \\
\hline $\begin{array}{l}\text { Jumlah sampah yang dihasilkan } \\
\text { dari lingkungan sekitar cukup } \\
\text { besar }\end{array}$ & 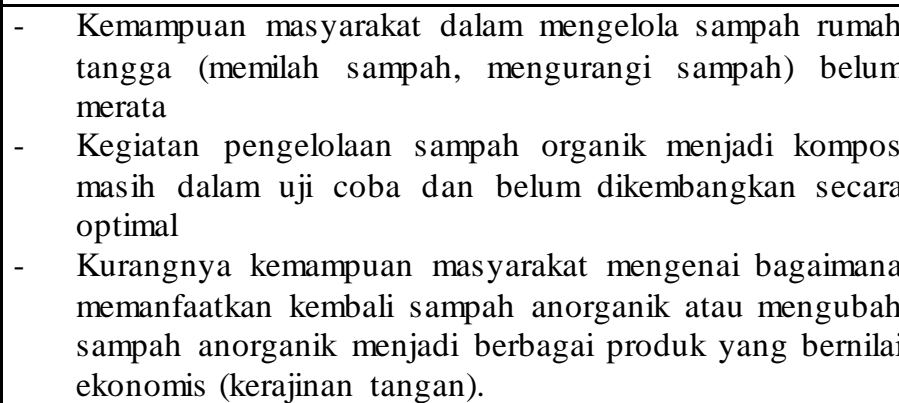 \\
\hline
\end{tabular}




\begin{tabular}{|c|c|}
\hline $\begin{array}{c}\text { Potensi dan sumber daya yang } \\
\text { dimiliki }\end{array}$ & Kendala / masalah yang dihadapi \\
\hline $\begin{array}{l}\text { Pelatihan-pelatihan keterampilan } \\
\text { yang telah dilakukan berkaitan } \\
\text { dengan pengelolaan sampah }\end{array}$ & $\begin{array}{l}\text { Kemampuan atau keterampilan hasil pelatihan tidak } \\
\text { termanfaatkan menjadi sebuah modal untuk memulai } \\
\text { melakukan hal yang sama di lingkungan tempat tinggal } \\
\text { Kemampuan untuk mengimplementasikan hasil pelatihan } \\
\text { menjadi kegiatan yang terjadwal dan dikelola dengan baik }\end{array}$ \\
\hline
\end{tabular}

\section{Metode Pelaksanaan}

Solusi yang ditawarkan untuk menyelesaikan masalah dengan memanfaatkan potensi yang ada adalah memberikan pelatihan dan pendampingan. Kegiatan transfer knowledge akan dilakukan melalui kegiatan pelatihan maupun kegiatan pendampingan. Kegiatan atau langkah-langkah yang akan dilakukan dalam peningkatan peran serta masyarakat dalam pengelolaan sampah melalui manajemen bank sampah adalah sebagai berikut:

1) Studi pendahuluan dan identifikasi kegiatan yang dibutuhkan

Pada tahap awal akan dilakukan studi pendahuluan mencakup identifikasi lebih lengkap mengenai kondisi sosio ekonomi masyarakat mitra, kondisi bank sampah yang telah ada, serta identifikasi jenis kegiatan yang dibutuhkan mitra.

2) Menyusun rencana pelaksanaan kegiatan

Tahap selanjutnya adalah menyusun rencana dan jadwal pelaksanaan kegiatan berdasarkan kesepakatan dengan mitra PKM sehingga diharapkan seluruh kegiatan yang diusulkan dapat terlaksana dengan baik sesuai dengan tujuan yang ingin dicapai dan waktu yang ditentukan.

\section{3) Melaksanakan Pelatihan}

Jenis pelatihan yang akan diberikan kepada mitra pada dasarnya terdiri dari pelatihan mengenai pemilahan, pengelolaan sampah organik (kompos), dan Kerajinan daur ulang apabila diperlukan.

Selain dilakukan kepada pengurus Bank Sampah mitra, pelatihan juga diberikan kepada masyarakat sekitar sebagai calon nasabah dalam mengelola sampah yang akan ditabung ke Bank Sampah.

4) Melakukan Pendampingan

Kegiatan pendampingan dilakukan untuk memastikan bahwa kegiatan pelatihan yang diberikan dapat memberikan dampak pada peran aktif masyarakat untuk melakukan semua hal yang sesuai dengan materi pelatihan. Kegiatan pendampingan meliputi memberikan bantuan dan bimbingan pada proses penyiapan peralatan dan tempat, melakukan praktek adminstrasi Bank Sampah, serta mendampingi mitra untuk mengelola Bank Sampah.

5) Monitoring dan Evaluasi program

Pada tahap ini akan dilakukan evaluasi mengenai hasil kegiatan yang telah dilakukan dan mengidentifikasi kendala-kendala yang dihadapi serta upaya untuk menyelesaikannya termasuk juga mengidentifikasi peluang-peluang untuk perluasan kegiatan yang lainnya seperti ke pengolahan sampah anorganik atau potensi pembentukan Bank Sampah. 


\section{Hasil Dan Pembahasan}

\subsection{Identifikasi kebutuhan pelatihan}

Bank sampah Mekar Sakinah berlokasi di Komplek perumahan Unisba RW. 12 Desa Mandala Mekar Kec. Cimenyan. Kegiatan rutin yang dilakukan Bank Sampah Mekar Sakinah adalah menampung sampah rumah tangga, barang bekas dalam bentuk kering hasil pemilahan sampah oleh warga di tiap rumah di RW 12 komplek Unisba. Tiap KK (Kepala Keluarga) yang menjadi nasabah Bank Sampah memiliki buku tabungan, berisi pencatatan banyaknya sampah dan rupiah yang dikumpulkan di Bank sampah. Sampah -sampah yang terkumpul untuk kemudian dipilah-pilah berdasarkan jenisnya dan dijual kepada Bandar sampah. Nasabah Bank sampah berhak mengambil nilai uang yang ditabung minimal setelah 6 bulan. Sampah plastik kemasan (bekas bungkus makanan, cangkang kopi, bungkus softener, deterjen, dan lainnya) dikumpulkan oleh bank sampah untuk selanjutnya akan dibuat menjadi barang kerajinan. Kegiatan pengumpulan sampah dilakukan setiap minggu ke-2 dan ke-4 setiap bulannya. Sedangkan untuk sampah organik/basah dibuat percontohan pembuatan pupuk kompos di dekat areal tempat pembuangan sampah.

Pada awal berdirinya bank sampah ini memiliki 55 nasabah, tetapi setiap tahun jumlah nasabah terus menurun. Data jumlah nasabah dapat dilihat pada Tabel 2.Menurunnya jumlah nasabah tersebut mengakibatkan hasil penjualan bank sampah menurun. Hal tersebut diakibatkan jumlah sampah yang terkumpul lebih sedikit (Tabel $3)$.

Tabel 2: Jumlah Nasabah per Tahun

\begin{tabular}{|c|c|}
\hline Tahun & Jumlah Nasabah \\
\hline 2012 & 55 \\
\hline 2013 & 29 \\
\hline 2014 & 20 \\
\hline
\end{tabular}

Tabel 3: Hasil Penjualan per Tahun

\begin{tabular}{|c|c|}
\hline Tahun & Hasil Penjualan \\
\hline Tahun 2012 & 1695.600 \\
\hline Tahun 2013 & 1485.150 \\
\hline Tahun 2014 & 1145.450 \\
\hline
\end{tabular}

Menurunnya jumlah nasabah disebabkan oleh masih rendahnya kesadaran masyarakat terhadap lingkungan. Hal ini dapat dilihat dari banyaknya tumpukan sampah yang dibuang diarea dekat bank sampah (Gambar 1). Larangan untuk membuang sampah di tempat tersebutpun masih diabaikan warga (Gambar 2). Sampah organik dan anorganik tercampur dalam satu tempat. Tempat pembuatan kompos yang telah tersedia tidak dapat difungsikan secara optimal, dikarenakan sulit memisahkan sampah yang telah tercampur. Tempat pembuatan kompos hampir terkubur oleh tumpukan sampah (Gambar 3). 


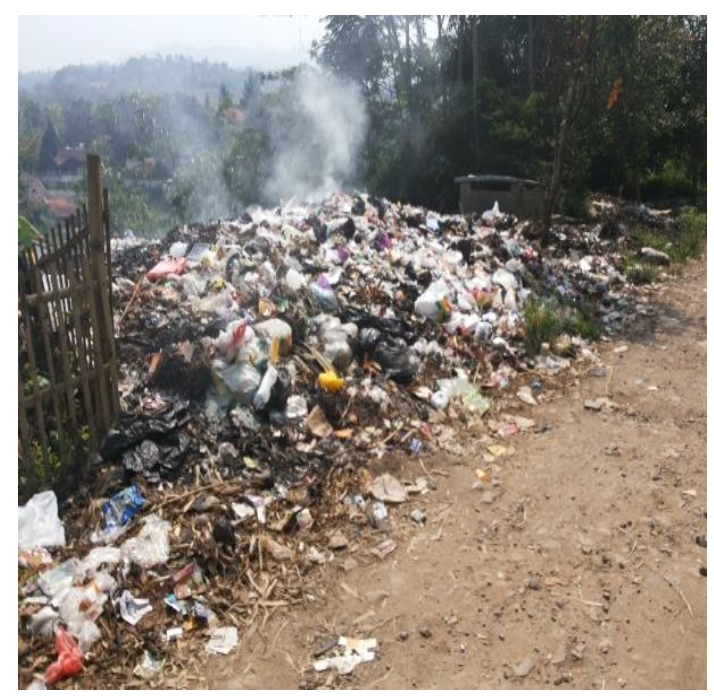

Gambar 1: Tumpukan Sampah

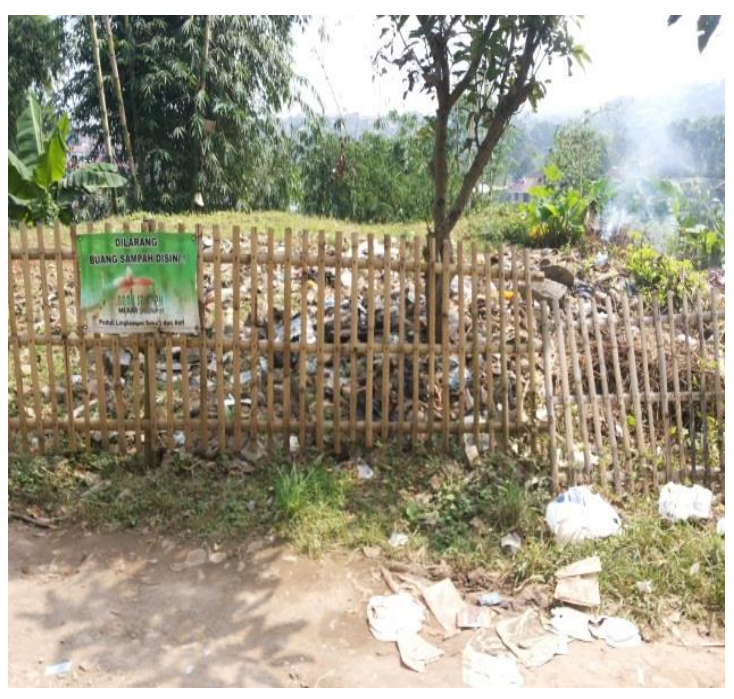

Gambar 2: Himbauan Larangan Pembuangan Sampah

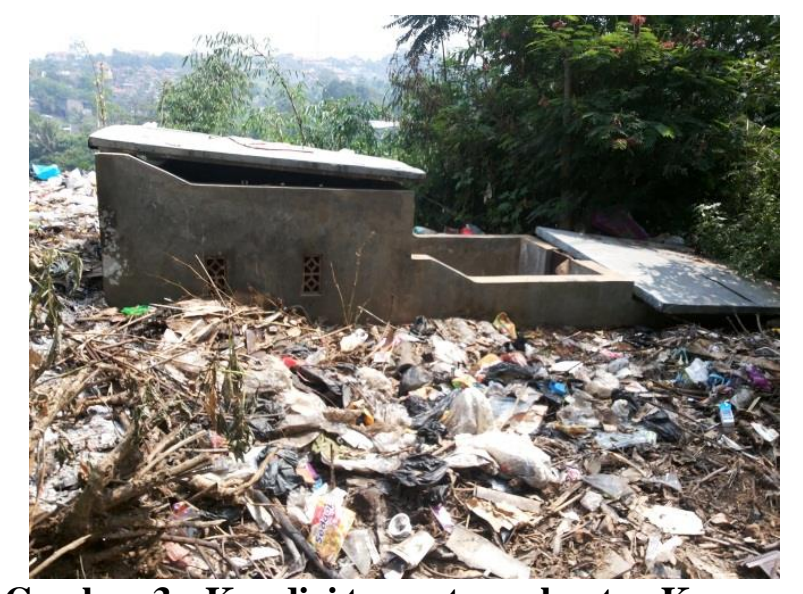

Gambar 3.: Kondisi tempat pembuatan Kompos

Berdasarkan hal-hal tersebut, maka diperlukan pelatihan kepada masyarakat untuk meningkatkan keperdulian terhadap lingkungan dan meningkatkan jumlah nasabah bank sampah Mekar Sakinah. Pelatihan yang diperlukan adalah:

1. Pelatihan pemilahan sampah

2. Pelatihan pembuatan kompos skala rumah tangga

Peserta pelatihan adalah warga sekitar bank sampah, yaitu warga Komplek perumahan Unisba RW. 12 Desa Mandala Mekar Kec. Cimenyan. Penyebab lain dari pengelolaan bank sampah Mekar Sakinah yang belum optimal, adalah keterbatasan sumber daya manusia dan fasilitas.

Aktivitas pengelolaan sampah dilakukan di kantor Bank Sampah Mekar Sakinah, yang terdiri dari satu ruangan kantor dan toilet. Di dalam ruangan tidak terdapat fasilitas kerja seperti meja, kursi dan yang lainnya. Saat ini fungsi ruangan seperti gudang tempat penyimpanan sampah yang disetor nasabah, karena tidak memiliki wadah untuk menampung sampah tersebut. Papan nama yang terpasang di depan kantor sederhana dan kurang representatif. Oleh karena itu untuk menunjang 
aktivitas pada bank sampah tersebut diperlukan fasilitas kerja berupa meja dan kursi kantor, display harga untuk memberikan informasi harga kepada nasabahnya, tempat penyimpanan barang yang disetorkan oleh nasabahnya sehingga dapat dipilah berdasarkan jenisnya, dan papan nama.

\subsection{Proses Bisnis Bank Sampah MekarSakinah}

Pengelolaan bisnis berbasis sampah seperti yang diterapkan pada bank sampah banyak sekali memberikan manfaat bagi masyarakat, seperti kebersihan lingkungan, kesehatan, hingga keuntungan ekonomi. Bisnis yang saat ini dikelola oleh Bank Sampah Mekar Sakinah adalah mengumpulkan dan menjual sampah anorganik. Selain itu mengelola sampah organic menjadi kompos, akan tetapi pengelolaan sampah organik ini masih belum optimal.

Pengelolaan sampah organik dimulai dari nasabah menyetorkan sampahnya, selanjutnya sampah tersebut ditimbang berdasarkan jenisnya, dan dicatat. Setelah sampah organik terkumpul, sampah tersebut dijual ke bandar atau pengepul. Mekanisme secara lengkap dari kerja bank sampah ditunjukan pada Gambar 4.

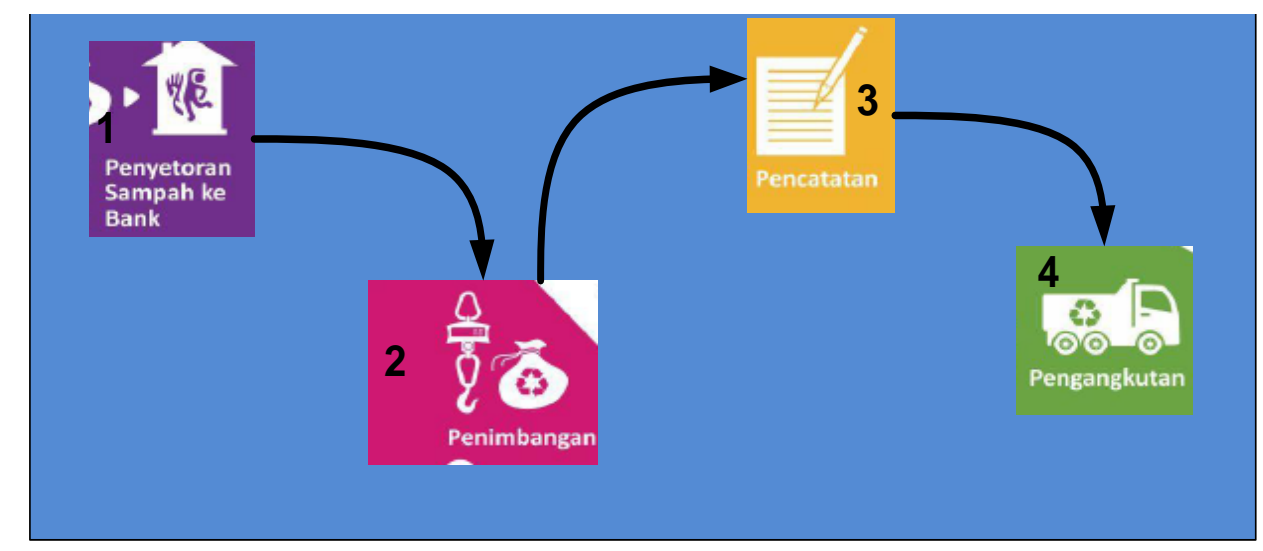

Gambar 4: Mekanisme Kerja Bank Sampah

1. Penyetoran sampah ke bank

Penyetoran sampah dilakukan dua minggu sekali, yaitu pada minggu ke dua dan empat. Aktivitas pertama adalah melakukan pelayanan kepada nasabah yang akan menyetorkan sampahnya, selanjutnya petugas bank sampah menerima sampah yang akan ditabung beserta buku tabungannya.

2. Penimbangan oleh petugas bank

Sampah yang telah disetorkan oleh nasabah ke petugas bank selanjutnya diterima oleh divisi penimbangan untuk ditimbang. Sebelum melakukan penimbangan petugas terlebih dahulu mengecek data nasabah, selanjutnya sampah akan dipilah sesuai dengan jenisnya. Setelah dipilah sampah akan ditimbang sesuai jenisnya.

3. Pencatatan oleh petugas bank

Setelah melakukan penimbangan petugas akan mencatat jenis dan bobot sampah yang disetorkan. Hasil pengukuran dan jenis sampah akan dikonversikan dalam rupiah yang kemudian akan dicatat dalam buku tabungan nasabah.

4. Penjualan sampah 
Sampah yang telah terkumpul selanjutnya dijual ke pengepul atau Bandar. Sebelum dilakukan penjualan, petugas akan memeriksa kembali sampah peritemnya, kemudian dilakukan pengepakan sampah dan disiapkan untuk dijual.

Berdasarkan mekanisme kerja bank sampah yang berjalan saat ini, dapat dilihat bahwa sistem kerja bank sampah ini tidak berbeda dengan sistem kerja pengepul, yaitu kumpul, pilah, dn angkut. Oleh karena itu diperlukan suatu proses untuk menciptakan nilai tambah pada sampah yang terkumpul di bank sampah, sehingga keberadaan bank sampah dapat menciptakan sampah dengan nilai ekonomis yang tinggi.

\subsection{Pelaksanaan Pelatihan}

Pelatihan dilaksanakan pada hari Sabtu, tanggal 30 Mei 2015, yang bertempat di Madrasah Nurul Mutaqien, yang berlokasi di perumahan Unisba Desa Mandala Mekar Kecamatan Cimenyan Kabupaten Bandung. Peserta pelatihan adalah ibu rumah tangga yang berdomisili di wilayah Bank Sampah Mekar Sakinah. Undangan yang disebarkan berjumlah 50 undangan, sedangkan yang hadir berjumlah 22.orang. Materi pelatihan terdiri dari:

1. Profil Bank Sampah Mekar Sakinah

Materi ini diberikan untuk memberikan informasi kepada masyarakat mengenai bank sampah Mekar Sakinah, khususnya kepada masyarakat yang belum menjadi nasabah.

2. Pemilahan sampah

Pemilahan sampah merupakan hal yang sangat penting dalam proses pengelolaan sampah. Pada materi ini dijelaskan jenis-jenis sampah, dan bagaimana cara pemilahan sampah. Oleh karena itu materi ini penting diberikan pada peserta pelatihan.

3. Pembuatan kompos skala rumah tangga

Pembuatan kompos skala komunal atau bersama yang dikelola bank sampah belum optimal. Hal ini dikarenakan sampah belum terpilah dengan baik dan keterbatasan tenaga kerja yang mengelola sampah organic tersebut. Oleh karena itu untuk pengelolaan sampah organik diberikan pelatihan mengenai pembuatan kompos skala rumah tangga.

\subsection{Pendampingan}

Kegiatan pendampingan dilakukan setelah kegiatan pelatihan. Hal ini bertujuan untuk memastikan bahwa kegiatan pelatihan dapat memberikan dampak pada peran aktif masyarakat untuk melakukan hal-hal yang sesuai dengan materi pelatihan. Kegiatan pendampingan meliputi pengadaan fasilitas kerja untuk menunjang aktivitas bank sampah dan mendampingi pengelolaan Bank Sampah. Fasilitas yang diberikan adalah papan nama, drum untuk tempat botol dan plastik, dan display untuk informasi harga (Gambar 5) . 


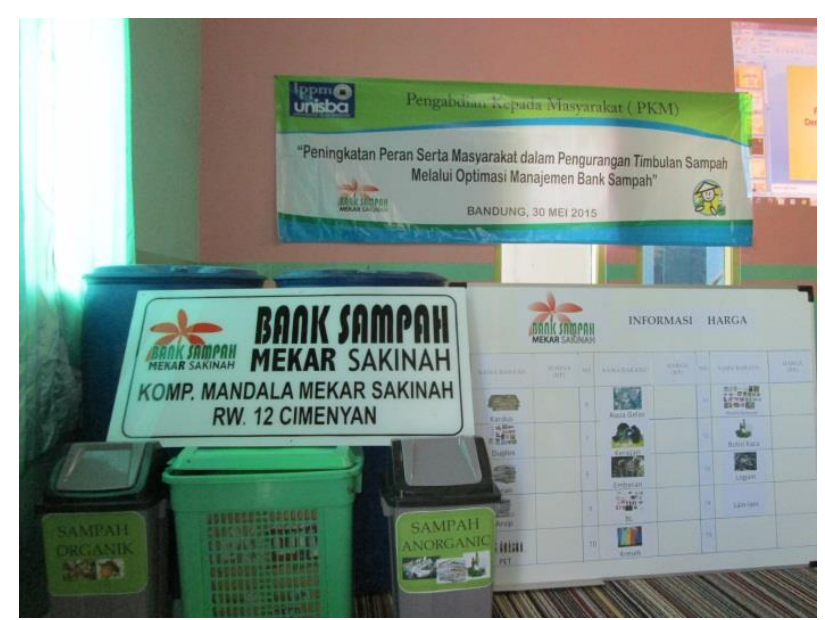

Gambar 5: Fasilitas yang diberikan

\subsection{Monitoring dan evaluasi}

Kegiatan pelatihan yang diberikan memberikan dampak positif terhadap aktivitas bank sampah. Dampak tersebut antara lain:

a. Adanya peningkatan jumlah nasabah pada bank sampah Mekar Sakinah.

Pada awal berdirinya bank sampah Mekar Sakinah memiliki 54 orang nasabah, tetapi setiap tahunnya mengalami penurunan (Tabel 2). Setelah dilakukan pelatihan terjadi pertambahan jumlah nasabah sebanyak sembilan nasabah. Nasabah lama yang awalnya sudah tidak aktif menjadi aktif kembali sebanyak lima nasabah, dan nasabah baru sebanyak empat nasabah.

b. Sosialisasi lebih mudah

Adanya bantuan alat peraga pemilahan dan takakura memudahkan pengurus bank sampah Mekar Sakinah dalam memberikan sosialisasi pemilahan sampah berdasarkan jenisnya dan pembuatan kompos skala rumah tangga.

c. Proses pemilahan lebih mudah

Adanya bantuan drum memudahkan pengurus bank sampah untuk memilah sampah yang akan dijual ke bandar sampah.

\section{Kesimpulan dan Saran}

Kesimpulan dari kegiatan yang telah dilaksanakan adalah sebagai berikut:

1) Berdasarkan hasil identifikasi menunjukkan bahwa masalah utama pada Bank Sampah Mekar sakinah adalah penurunan jumlah nasabah. Oleh karena itu diperlukan pelatihan kepada masyarakat untuk meningkatkan keperdulian terhadap lingkungan dan meningkatkan jumlah nasabah bank sampah Mekar Sakinah. Kegiatan yang dilakukan pada PKM ini adalah pelatihan mengenai pemilahan sampah dan pembuatan kompos skala rumah tangga. Selain itu penyediaan failitas kerja, yaitu papan nama, drum, display harga.

2) Pelatihan dilaksanakan tanggal 30 Juni 2015 di komp. Perumahan Unisba. Materi yang diberikan adalah profil Bank Sampah Mekar Sakinah, pemilahan sampah, dan pembuatan kompos skala rumah tangga. 
170 | Yanti Sri Rezeki, et al.

3) Kegiatan PKM ini berdampak pada peningkatan jumlah nasabah bank sampah sebanyak sembilan orang.

Saran dari kegiatan PKM yang telah dilaksanakan untuk PKM berikutnya adalah sebagai berikut:

1) Bantuan fasilitas yang diberikan untuk menunjang aktivitas Bank Sampah Mekar Sakinah masih belum terpenuhi, oleh karena itu untuk memenuhi semua kebutuhan tersebut dapat dilakukan pada PKM berikutnya.

2) Pelatihan pengelolaan sampah nonorganic

3) Sosialisai, monitoring dan pendampingan terhadap kegiatan Bank Sampah sebaiknya dilakukan secara berkala.

\section{Daftar Pustaka}

Kementrian Lingkungan Hidup RI, 2011,Bank Sampah Dan 3R :Membangun Lingkungan Dan Ekonomi Kerakyatan 